\title{
The effect of very low-calorie diets on renal and hepatic outcomes: a systematic review
}

This article was published in the following Dove Press journal:

Diabetes, Metabolic Syndrome and Obesity:Targets and Therapy

10 October 2013

Number of times this article has been viewed

\author{
Catherine Rolland' \\ Alexandra Mavroeidi ${ }^{2}$ \\ Kelly L Johnston ${ }^{3}$ \\ John Broom ${ }^{1,3}$ \\ 'Centre for Obesity Research and \\ Epidemiology (CORE), Faculty of \\ Health and Social Care, Robert \\ Gordon University, Aberdeen, \\ Scotland, UK; ${ }^{2}$ School of Medical \\ Sciences, College of Life Sciences and \\ Medicine, University of Aberdeen, \\ Aberdeen, Scotland, UK; ${ }^{3}$ LighterLife \\ Ltd, Harlow, Essex, UK
}

\begin{abstract}
Very low-calorie diets (VLCDs) are an effective means by which to induce clinically significant weight loss. However, their acceptance by health care practitioners and the public is generally lower than that for other nonsurgical weight loss methods. Whilst there is currently little evidence to suggest they have any detrimental effect on hepatic and renal health, data assessing these factors remain limited. We carried out a systematic review of the literature on randomized controlled trials that had a VLCD component and that reported outcomes for hepatic and renal health, published between January 1980 and December 2012. Cochrane criteria were followed, and eight out of 196 potential articles met the inclusion criteria. A total of 548 participants were recruited across the eight studies. All eight studies reported significant weight loss following the VLCD. Changes in hepatic and renal outcomes were variable but generally led to either no change or improvements in either of these. Due to the heterogeneity in the quality and methodology of the studies included, the effect of VLCDs on hepatic and renal outcomes remains unclear at this stage. Further standardized research is therefore required to fully assess the impact of VLCDs on these outcome measures, to better guide clinical practice.
\end{abstract}

Keywords: obesity, liver, kidney, weight loss, health

\section{Introduction}

The prevalence of overweight and obesity is increasing globally, and effective weight loss treatment is of great importance from both a health and socioeconomic perspective. ${ }^{1}$ Very low-calorie diets (VLCDs) are an effective means by which to induce a clinically significant weight loss. ${ }^{2}$ However, their acceptance by health care practitioners and the public, in general, is much lower than that for other nonsurgical weight loss methods. This is likely to be due to the adverse effects of the nutritionally insufficient VLCDs that were popular in the 1970 s, which resulted in a number of deaths due to vitamin and mineral deficiencies and consumption of poor quality or inadequate amounts of protein. ${ }^{3,4}$ The VLCDs of the past were, however, completely different from the nutritionally replete variants of modern day VLCDs, and despite the fact that fast weight loss, seen in followers of a VLCD, is still generally perceived as being unsafe, there is no convincing evidence to suggest that this is the case. Indeed, the European Food Safety Authority has approved a health claim with regards to the efficacy of VLCDs on weight loss, in a target population of obese adults. ${ }^{5}$

A VLCD is defined as a diet of $<800 \mathrm{kcal} / \mathrm{day},{ }^{6}$ and there are many commercially available variants that provide energy intakes between $300-800 \mathrm{kcal} /$ day.

There is sufficient evidence in the literature to ensure the safe use of VLCDs in healthy overweight and obese patients in the short term; ${ }^{7,8}$ however, there remains 
limited evidence on the effects of VLCDs on specific disease groups over this same period of time. This is likely to, in part, be due to the strict protocols and monitoring that are advised with this type of dietary approach to weight loss. Although the evidence for the benefits of VLCDs is mounting in certain groups of individuals at higher cardiovascular risk, for example those with type 2 diabetes mellitus, ${ }^{9,10}$ there is little evidence of outcomes in patients with other obesity-related secondary diseases, such as nonalcoholic fatty liver disease (NAFLD). In a recent review, Mulholland et al, ${ }^{2}$ investigating long-term ( $>12$ months) randomized control trials of VLCD, identified only two reports of studies that evaluated effects on liver and kidney function. ${ }^{11,12}$ One paper $^{11}$ described that at 2 years follow up, there were no significant changes in liver transaminases. The other paper ${ }^{12}$ reported both statistically and biologically significant improvements in both hepatic and renal health, including changes in alanine aminotransferase, alkaline phosphatase, $\gamma$-Glutamyl transferase, creatinine, estimated glomerular filtration rate (eGFR), and urea. The observed changes in liver enzymes indicated an improvement in hepatic steatosis and an improvement in the biochemical markers associated with renal and hepatic pathology.

Furthermore, a recent study by Lim et al ${ }^{13}$ reported that in patients with type 2 diabetes mellitus who followed a VLCD, the resulting acute negative energy balance reversed the type 2 diabetes mellitus by normalizing both insulin sensitivity and beta cell function. The authors suggested this result was due to the reduction of fat in the liver and pancreas. These results are in keeping with our previous findings, which demonstrated improvements in liver enzymes following a VLCD. ${ }^{12}$

Whilst there is currently little evidence to suggest VLCDs cause any detriment to liver or kidney health, data assessing these factors remain limited. Thus, we aimed to carry out a systematic review of the literature and of studies investigating a VLCD and reporting outcomes for liver and kidney health, published between January 1980 and December 2012.

\section{Methods}

The protocol used for this systematic review follows the methods recommended by the Cochrane Collaboration. ${ }^{14}$ Further details of the approach are described below.

\section{Inclusion criteria}

This review was intended to assess the literature in this field. Studies from January 1980 to December 2012 were evaluated. Studies prior to 1980 were not included, due to health concerns associated with the formulations of the VLCDs in the 1970s. ${ }^{3,4}$ Only investigations of adult (18 years and over) participants with a mean or median body mass index (BMI) of $\geq 28 \mathrm{~kg} / \mathrm{m}^{2}$ were included, and only randomized, controlled trials with a VLCD component were evaluated. Variations in the duration of the intervention which were aimed at achieving weight loss (ie, active weight loss prior to weight maintenance approaches) were recorded and accounted for, where possible.

\section{Types of interventions}

The focus of this review was to examine the effect of VLCDs on hepatic and renal outcomes. The types of dietary interventions evaluated were VLCDs (also known as very low-energy diets), defined as a dietary intake of $800 \mathrm{kcal} /$ day or less.

\section{Outcome measures}

Weight loss was the main outcome assessed in the studies included in the review. With regard to hepatic or renal status, the following outcomes were also included:

- Liver enzymes (alanine aminotransferase [ALT], alkaline phosphatase [ALKP], aspartate transaminase [AST], gamma-glutamyl transpeptidase [GGT], and albumin)

- Electrolytes and markers of urea and kidney function (sodium, potassium, chloride, creatinine, and eGFR)

- NAFLD.

\section{Search strategy for the identification of included studies}

This systematic review was restricted to studies where the full study report was available. A search strategy on MEDLINE was applied to identify as many as possible of the studies evaluating dietary interventions using VLCDs and relevant to hepatic and renal status. The search strategy incorporated the terms "very low calorie diet" and "very low energy diet." Authors were contacted for further details of their trials and the reference lists of included studies and reviews were also searched.

\section{Quality assessment of studies}

The protocol used for the quality assessment followed the methods recommended by Avenell et al. ${ }^{15}$ The studies were classified as having either a low risk of bias (A), an unclear risk of bias (B), or a high risk of bias (C). The subset "I" suggested that a description was provided, while the subset "II" suggested that no description was provided.

Full copies of studies were assessed by two researchers, for methodological quality. The researchers were not blinded to the author, journal, or institution. Differences of opinion were resolved by discussion. The trial quality was assessed 
and included a consideration of whether or not the analysis was undertaken on an intention-to-treat basis.

\section{Identified studies}

A total of eight out of 196 articles met the inclusion criteria and were included in the systematic review. The reasons for the exclusion of studies are summarized in Figure 1.

\section{Results}

\section{Study characteristics}

A total of 548 participants were recruited across the eight studies included in this systematic review. There was a large amount of heterogeneity in the study design for the papers meeting the inclusion criteria. The studies included ranged from 8 weeks ${ }^{16}$ to 2 years $^{11}$ in duration. The duration of the VLCDs ranged from 25 days ${ }^{11}$ to 9 months. ${ }^{12}$ In the follow-up phase, different studies incorporated aspects of behavior modification, ${ }^{11}$ reduced calorie intake, ${ }^{17-19}$ or medication (acarbose) (Table 1). ${ }^{20}$

All of the studies were designed to reduce weight or prevent weight gain and also examined hepatic and renal outcomes. The results of all the studies are summarized in Table 1.

\section{Quality assessment}

Table 2 displays the quality assessment of the reported studies. All of the studies were randomized, but the allocation

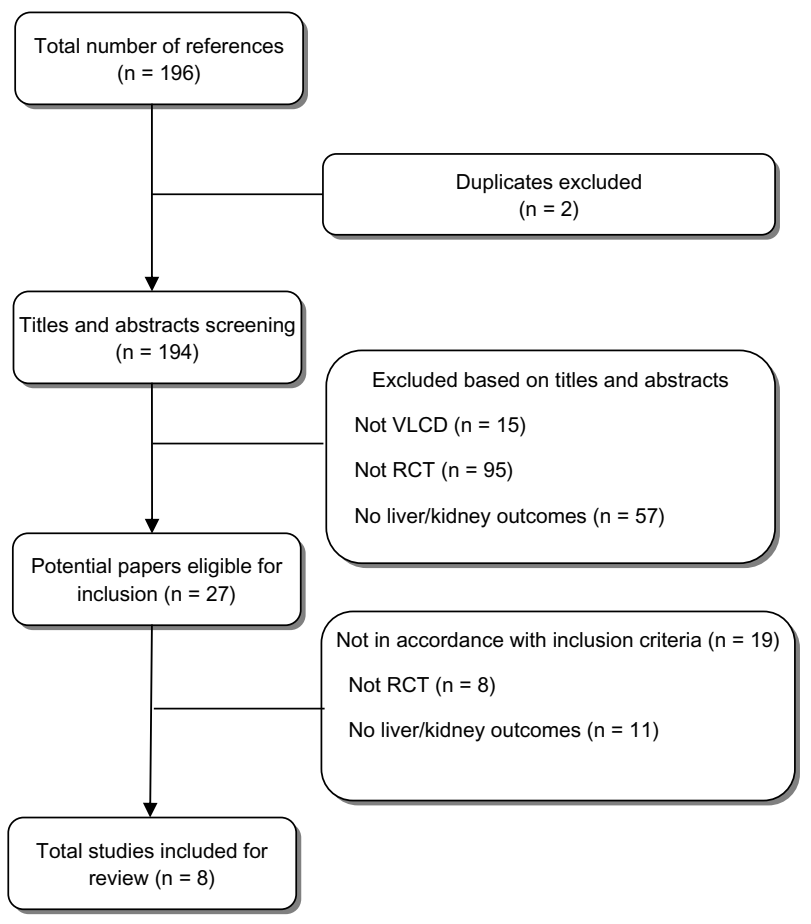

Figure I Summary of the literature search. Abbreviations: RCT, randomized controlled trial; VLCD, very low-calorie diet. description was generally not provided, with the exception of one paper, ${ }^{21}$ in which the method of concealment had a real chance of disclosure of assignment prior to formal trial entry. Four studies ${ }^{11,18-20}$ clearly stated the numbers and reasons for withdrawal from the study, while two studies ${ }^{12,21}$ only provided the numbers of withdrawals, and two studies ${ }^{16,17}$ made no mention of dropouts. Three studies analyzed the data with the intention to treat, ${ }^{12,20,21}$ while three ${ }^{16,17,19}$ may also have done so, but the methods of analysis were unclear, and the final two studies ${ }^{11,18}$ presented data for completers only. Participants as well as health care providers were blinded to the treatment in two studies (of a test emulsion, ${ }^{18}$ and acarbose, ${ }^{20}$ respectively); participants were not blinded in the other six studies, and it was unclear whether the health care providers or the outcome assessors were blinded to treatment status.

\section{Weight change}

All eight of the studies resulted in significant weight loss following the VLCD period (Table 2). Where weight change was reported after a follow-up period, the implementation of any of a reduced-calorie diet, ${ }^{17}$ regular support through intensive or less intensive behavior modification therapy, ${ }^{11}$ meal replacement once a day, ${ }^{18}$ or ongoing use of $\mathrm{VLCD}^{12}$ resulted in the maintenance of significant weight loss compared with baseline. Although no values for weight change were provided, Hauner et $\mathrm{al}^{20}$ stated that the use of acarbose resulted in individuals remaining at a stable weight for the weeks following the VLCD (Table 2).

\section{Hepatic outcomes}

Table 3 displays the results for different hepatic outcomes reported in three of the studies. Arai et al ${ }^{16}$ observed an improvement in AST and ALT following the VLCD. Rolland et $\mathrm{al}^{12}$ also reported an improvement in ALT as well as in ALKP, GGT, and albumin following the VLCD period. Melin et $\mathrm{al}^{11}$ provided baseline values but only anecdotally reported (ie, no values were presented) that there were no changes in the liver transaminases.

Two other studies reported anecdotal results of changes in hepatic outcomes. Olsson et $\mathrm{al}^{18}$ reported that ALT levels increased significantly during the weight-reduction phase but were normalized during the 12-week weight maintenance phase, whereas Hauner et $\mathrm{al}^{20}$ reported that no changes were observed in the serum transaminases in participants undergoing a VLCD followed by the use of acarbose.

Only one study investigated the effect of VLCDs on NAFLD. In the study by Lin et al, ${ }^{21} 41$ participants with NAFLD were placed on a $450 \mathrm{kcal} /$ day VLCD for 12 weeks. 
Table I Summary of studies included in the review

\begin{tabular}{|c|c|c|c|}
\hline Author & $\begin{array}{l}\mathbf{N} \\
\text { (males) }\end{array}$ & Study & $\begin{array}{l}\text { Mean BMI } \\
\left(\mathrm{kg} / \mathrm{m}^{2}\right)\end{array}$ \\
\hline $\begin{array}{l}\text { Arai } \\
\text { et } \text { al }^{16}\end{array}$ & $45(12)$ & $\begin{array}{l}\text { RCT in which patients undertook either } \\
\text { I. Supplemental LCD ( } 35 \mathrm{I} 5-502 \mathrm{I} \mathrm{kJ/d} \mathrm{with} \mathrm{use} \mathrm{of} 2-3 \text { packages of Optifast } 70 \text { and } \\
2678-3682 \mathrm{~kJ} \text { of conventional balanced meals consisting of a mixture of } 88 \mathrm{~g} \mathrm{P} \text {, } \\
30-80 \mathrm{~g} \text { CHO, } 4-9 \mathrm{~g} \mathrm{~F}) \text { or } \\
\text { 2. VLCD where participants used } 5 \text { packages of Optifast } 70 \text { (daily energy intake of } 1757 \mathrm{~kJ} \text {, } \\
70 \mathrm{~g} \text { protein, } 30 \mathrm{~g} \text { CHO, } 2 \mathrm{~g} \mathrm{~F} \text { ) }\end{array}$ & VLCD: $32.9(6.1)$ \\
\hline $\begin{array}{l}\text { Doherty } \\
\text { et } \text { al }^{17}\end{array}$ & $26(0)$ & $\begin{array}{l}\text { RCT in which patients received either } \\
\text { I. Control: diet of their choosing throughout the } 45 \text { weeks (control); } \\
\text { 2. VLCD: I week of a I } 200 \mathrm{kcal} / \mathrm{d} \text { BDD and a } 420 \mathrm{kcal} / \mathrm{d} \text { liquid diet for weeks } 2-17 \text {. Patients } \\
\text { were realimented during weeks I8-24 by increasing the daily caloric intake by extra } \\
\sim 150 \mathrm{kcal} \text { for each week of realimentation until reaching } \sim 1150 \mathrm{kcal} / \mathrm{d} \text { at week } 24 \text {. Patients } \\
\text { were instructed to consume a balanced diet providing } 1200-1500 \mathrm{kcal} / \mathrm{d} \text { for the remainder } \\
\text { of the treatment (weeks } 26-45 \text { ) } \\
\text { 3. BDD + exercise: consume a BDD providing } 1000-1500 \mathrm{kcal} / \mathrm{d}(\mathrm{I} \%-20 \% \text { protein; } \\
50 \%-55 \% \mathrm{CHO}, 30 \% \text { fat) for } 45 \text { weeks. Instructed (at week } 8 \text { ) to begin a program of aerobic } \\
\text { activity (mostly consisting of walking). Initially } 10-20 \text { minutes two to three times per week. } \\
\text { By end of study, they reported exercising for } 20-40 \text { minutes three to five times per week }\end{array}$ & $\begin{array}{l}\text { Control: } 33.4(2) \\
\text { VLCD: } 40.4(2)\end{array}$ \\
\hline $\begin{array}{l}\text { Hauner } \\
\text { et al }{ }^{20}\end{array}$ & $110(22)$ & $\begin{array}{l}\text { RCT in which patients underwent a pretreatment phase of VLCD/LCD } \\
(700-1000 \mathrm{kcal} / \mathrm{d} \text { ) to achieve a weight loss of at least } 2-3 \mathrm{BMI} \text { units. Afterwards, participants } \\
\text { were asked to maintain an individually tailored weight-maintaining diet and were either } \\
\text { prescribed a placebo or acarbose (treatment started with } 50 \mathrm{mg} \text { once/day and titrated up } \\
\text { to a maximum of } 100 \mathrm{mg} \text { tid at weekly intervals) }\end{array}$ & $\begin{array}{l}\text { Placebo: } 34.8(2.2) \\
\text { Acarbose: } 34.7(2.3)\end{array}$ \\
\hline Lin et $\mathrm{a}^{21}$ & $132(43)$ & $\begin{array}{l}\text { RCT in which patients undertook a } 2 \text {-week introduction phase during which they consumed } \\
\text { a I } 200 \mathrm{kcal} / \mathrm{d} \text { diet. This was followed by a } 450 \mathrm{kcal} / \mathrm{d} \text { VLCD or an } 800 \mathrm{kcal} / \mathrm{d} \text { VLCD for } \\
10 \text { weeks }\end{array}$ & $\begin{array}{l}\text { VLCD 450: } 34.4(3.5) \\
\text { VLCD 800: } 34.1 \text { (3.9) }\end{array}$ \\
\hline \multirow[t]{3}{*}{$\begin{array}{l}\text { Melin } \\
\text { et } \mathrm{al}^{\prime \prime}\end{array}$} & $43(4)$ & $\begin{array}{l}\text { RCT in which patients undertook a } 25 \text {-day VLCD followed by hypocaloric diet. Patients } \\
\text { were divided into two groups }\end{array}$ & \\
\hline & & $\begin{array}{l}\text { Group I: intensive behavior modification therapy every fortnight during the first year and } \\
\text { six meetings in the second year }\end{array}$ & Group I: $35.6(4.5)$ \\
\hline & & Group 2: planned meetings every third month & Group 2: $35.2(4.6)$ \\
\hline $\begin{array}{l}\text { Olsson } \\
\text { et al }{ }^{18}\end{array}$ & $43(0)$ & $\begin{array}{l}\text { RCT in which patients were assigned to a } 6 \text {-week VLCD to achieve at least a } 5 \% \text { reduction } \\
\text { in body weight, after which they resumed habitual eating patterns except for lunch, which } \\
\text { was replaced by Nutrilett }{ }^{\circledR} \text { Intensive meal ( } 1 \text { I l kcal) mixed with a control or a test emulsion }\end{array}$ & $\begin{array}{l}\text { Control: } 28.3(1.6) \\
\text { Emulsion: } 28.2(1.4)\end{array}$ \\
\hline $\begin{array}{l}\text { Rolland } \\
\text { et al' }\end{array}$ & $120(11)$ & $\begin{array}{l}\text { RCT where patients were assigned to a } 600 \text { calorie-deficit diet for } 3 \text { months. Those who did not } \\
\text { achieve a } 5 \% \text { weight loss were randomized to either: LCHP or VLCD for the following } 9 \text { months }\end{array}$ & $\begin{array}{l}\text { LCHP: } 41.6(4.8) \\
\text { VLCD: } 46.0(7.0)\end{array}$ \\
\hline $\begin{array}{l}\text { Ryttig and } \\
\text { Rössner }\end{array}$ & $60(11)$ & $\begin{array}{l}\text { RCT in which patients were assigned to } 12 \text { weeks of VLCD followed by a gradual increase } \\
\text { of normal food during I week. After transition, patients were assigned to either: }\end{array}$ & \\
\hline & & $\begin{array}{l}\text { Group I: normal, well-balanced hypocaloric diet containing } 1600 \mathrm{kcal} / \mathrm{d} \text {, of which } 220 \mathrm{kcal} \\
\text { was provided by two sachets of the Cambridge diet }\end{array}$ & Group I: $38.0(4.9)$ \\
\hline & & Group 2: normal, well-balanced hypocaloric diet containing $1600 \mathrm{kcal} / \mathrm{d}$ of solid food only & Group 2: $40.3(6.0)$ \\
\hline
\end{tabular}

Notes: Values are reported as mean (standard deviations), unless stated otherwise. $\Delta$ represents a change. ${ }^{\text {a }} p<0.05$ from baseline; ${ }^{\mathrm{b}} P<0.00 \mathrm{I}$ from baseline; ${ }^{\mathrm{c} P}<0.000 \mathrm{I}$ from baseline; ${ }^{\mathrm{d}} \mathrm{P}<0.05$ between groups; ${ }^{\mathrm{P}}<0.00$ I between groups.

Abbreviations: BDD, balanced deficient diet; BMI, body mass index; CHO, carbohydrate; F, fat; kJ/d, kilojoules per day; LCD, low-calorie diet; LCHP, low carbohydrate high protein; P, protein; RCT, randomized controlled trial; SE, standard error; SLCD, supplemental low-calorie diet; tid, three times daily; VLCD, very low-calorie diet.

In this group, a $41.5 \%$ improvement rate in NAFLD was reported, where five of the 41 participants no longer had NAFLD, and others had improvements in severity; however, of the five participants in this group who did not have NAFLD at the beginning of the intervention, two had developed NAFLD by the end of the intervention. Lin et $\mathrm{al}^{21}$ also had participants on an $800 \mathrm{kcal} / \mathrm{d}$ VLCD. In this latter group, they observed a $50 \%$ improvement rate, where of the 42 participants who initially presented with NAFLD, ten no longer had NAFLD, and of the five participants who did not have NAFLD at baseline, none developed it.

\section{Renal outcomes}

Table 4 displays the results of the renal outcomes from the only paper $^{12}$ that provided values for changes in renal function. 


\begin{tabular}{|c|c|c|c|c|c|}
\hline Inclusion criteria & $\begin{array}{l}\text { Duration } \\
\text { of VLCD }\end{array}$ & $\begin{array}{l}\text { Duration of } \\
\text { follow up }\end{array}$ & $\begin{array}{l}\text { Weight (kg) } \\
\text { at baseline }\end{array}$ & $\begin{array}{l}\text { Weight }(\mathrm{kg}) \text { at the } \\
\text { end of the VLCD } \\
\text { period }\end{array}$ & $\begin{array}{l}\text { Weight (kg) at the } \\
\text { end of the follow up }\end{array}$ \\
\hline \multirow[t]{2}{*}{ and women } & 8 weeks & - & SLCD: 81.5 (I4.0) & SLCD: $76.3(14.7)^{\mathrm{a}}$ & - \\
\hline & & & VLCD: 82.0 (20.0) & VLCD: $73.0(16.3)^{\mathrm{a}}$ & \\
\hline \multirow[t]{3}{*}{ Obese women } & 15 weeks & 29 weeks & Control: 94.7 (5.0) & Control: $\Delta 2.7$ (I.2) & Control: $\Delta 3.9$ (2.3) \\
\hline & & & VLCD: I I I.2 (5.0) & VLCD: $\Delta-21.3(2.1)^{\mathrm{a}, \mathrm{d}}$ & VLCD: $\Delta-22.4(3.4)^{\mathrm{a}, \mathrm{d}}$ \\
\hline & & & $\begin{array}{l}\text { BDD + exercise: } \\
102.8(6)\end{array}$ & $\begin{array}{l}\text { BDD + exercise: } \\
\Delta-10.3(2.7)^{\mathrm{a}, \mathrm{d}}\end{array}$ & $\begin{array}{l}\text { BDD + exercise: } \\
\Delta-14.5(5.5)^{a, d}\end{array}$ \\
\hline $\begin{array}{l}\text { Weight stable } \\
\text { obese subject with } \\
\text { BMI } 32-38 \mathrm{~kg} / \mathrm{m}^{2}\end{array}$ & $10-16$ weeks & 26 weeks & $\begin{array}{l}\text { Placebo: } 97.8 \text { (13.0) } \\
\text { Acarbose: } 97.7(13.5)\end{array}$ & No values & $\begin{array}{l}\text { Placebo: } \Delta 0.6 \mathrm{~kg} \\
\text { Acarbose: weight stable } \\
\text { (no values) }\end{array}$ \\
\hline $\begin{array}{l}\text { Obese }\left(\mathrm{BMI} \geq 30 \mathrm{~kg} / \mathrm{m}^{2}\right) \\
\text { Taiwanese between the ages } \\
\text { of } 18-65 \text { years }\end{array}$ & 10 weeks & - & $\begin{array}{l}450 \mathrm{kcal} / \mathrm{d}: 92.5(14.1) \\
800 \mathrm{kcal} / \mathrm{d}: 92.1(15.6)\end{array}$ & $\begin{array}{l}450 \mathrm{kcal} / \mathrm{d}: \\
\Delta-8.37(0.70)^{\mathrm{b}} \\
800 \mathrm{kcal} / \mathrm{d}: \\
\Delta-8.42(0.70)^{\mathrm{b}}\end{array}$ & - \\
\hline $\begin{array}{l}\text { Men and women; } \\
\text { 24-60 years old; }\end{array}$ & 25 days & 2 years & & & \\
\hline \multirow{2}{*}{$\begin{array}{l}\text { 24-60 years old; } \\
\text { BMI } 35 \text { kg/m² (29-48) }\end{array}$} & & & Group I: 99.8 (5.5) & $\begin{array}{l}\text { Group I: } \\
\Delta-8.3(0.64)^{\mathrm{b}}\end{array}$ & $\begin{array}{l}\text { Group I: } \Delta-6.8 \\
(\mathrm{I} .4)^{\mathrm{a}}\end{array}$ \\
\hline & & & Group 2: 93.4 (4.I) & $\begin{array}{l}\text { Group 2: } \\
\Delta-10.0(0.71)^{b}\end{array}$ & $\begin{array}{l}\text { Group 2: } \\
\Delta-8.6(1.6)^{\mathrm{a}}\end{array}$ \\
\hline Female; 18-60 years; & 6 weeks & 12 weeks & Control: 79.0 (8.3) & Control: $7 \mathrm{I} .5(7.1)^{\mathrm{a}}$ & Control: $70.2(6.9)^{\mathrm{a}}$ \\
\hline BMI $26-31 \mathrm{~kg} / \mathrm{m}^{2}$ & & & Test emulsion: 79.7 (6.I) & Test emulsion: $73.0(5.3)^{\mathrm{a}}$ & emulsion: $72.0(5.6)^{\mathrm{a}}$ \\
\hline $\begin{array}{l}\text { Men and women; > }>8 \text { years } \\
\text { old; } B M I \geq 35 \mathrm{~kg} / \mathrm{m}^{2}\end{array}$ & $\begin{array}{l}6.9 \text { months } \\
\text { (4-9 months) }\end{array}$ & - & $\begin{array}{l}\text { LCHP: I I } 0.4(12.2) \\
\text { VLCD: I } 29.6(23.0)\end{array}$ & - & $\begin{array}{l}\text { LCHP: I09.I (14.6) } \\
\text { VLCD: } 98.0(20.3)^{\mathrm{c}, \mathrm{e}}\end{array}$ \\
\hline $\begin{array}{l}\text { Obese men and women (BMI } \geq 30 \\
\left.\mathrm{~kg} / \mathrm{m}^{2}\right) \text {, between } 19-65 \text { years, } \\
\text { with stable body weight within } \\
\text { the previous } 2 \text { months (less than } \\
3 \mathrm{~kg} \text { fluctuation) }\end{array}$ & 12 weeks & 52 weeks & $\begin{array}{l}\text { Solid food: } \\
\text { I20.I (22.5) } \\
\text { Meal replacement: } \\
\text { 108.I (15.8) }\end{array}$ & $\begin{array}{l}\text { Solid food: } \\
97.6(19.1)^{\mathrm{a}, \mathrm{d}} \\
\text { Meal replacement: } \\
85.7(14.7)^{\mathrm{a}}\end{array}$ & $\begin{array}{l}\text { No significant change } \\
\text { during the weight } \\
\text { maintenance period } \\
\text { between the groups } \\
\text { (no values provided) }\end{array}$ \\
\hline
\end{tabular}

The results demonstrated an improvement in creatinine, urea, and eGFR levels in response to a VLCD.

Two other studies reported anecdotal outcomes for renal function. Doherty et $\mathrm{al}^{17}$ reported that there were no significant changes in potassium, sodium, or chloride observed at 45 weeks in response to a VLCD followed by a balanced deficit diet. Similarly, Ryttig and Rössner ${ }^{19}$ reported that there were no significant changes in serum electrolytes (sodium, potassium) at the end of the 12 weeks of VLCD or during the weight maintenance period, between the two groups (balanced hypocaloric diet with or without a meal replacement component).

\section{Discussion}

As expected from previous studies, the VLCD interventions resulted in significant weight loss. The changes in hepatic and 
Table 2 Quality assessment of included RCTs

\begin{tabular}{|c|c|c|c|c|c|c|}
\hline & $\begin{array}{l}\text { Quality of } \\
\text { random allocation } \\
\text { concealment }\end{array}$ & $\begin{array}{l}\text { Description of } \\
\text { withdrawals } \\
\text { and dropouts }\end{array}$ & $\begin{array}{l}\text { Intention } \\
\text { to treat? }\end{array}$ & $\begin{array}{l}\text { Participants } \\
\text { blinded to } \\
\text { treatment status? }\end{array}$ & $\begin{array}{l}\text { Healthcare providers } \\
\text { blinded to treatment } \\
\text { status? }\end{array}$ & $\begin{array}{l}\text { Outcome assessors } \\
\text { blinded to treatment } \\
\text { status? }\end{array}$ \\
\hline Arai et al ${ }^{16}$ & B (I) & C & B & $C$ & $\mathrm{~B}(\mathrm{I})$ & B (I) \\
\hline Doherty et al ${ }^{17}$ & B (I) & C & B & C & B (I) & B (I) \\
\hline Hauner et $\mathrm{a}^{20}$ & B (I) & $A$ & A & A (II) & A (II) & B (I) \\
\hline Lin et $\mathrm{a}^{21}$ & B (II) & $\mathrm{B}(\mathrm{I})$ & $A$ & C & B (I) & B (I) \\
\hline Melin et al" & B (I) & $A$ & C & C & $\mathrm{B}(\mathrm{I})$ & B (I) \\
\hline Olsson et al ${ }^{18}$ & B (I) & $A$ & C & A (II) & A (II) & B (I) \\
\hline Rolland et $\mathrm{al}^{12}$ & $B(I)$ & $\mathrm{B}(\mathrm{I})$ & A & C & $B(I)$ & B (I) \\
\hline Ryttig and & B (I) & $A$ & B & C & $\mathrm{B}(\mathrm{I})$ & B (I) \\
\hline Rössner ${ }^{19}$ & & & & & & \\
\hline
\end{tabular}

Notes: A = low risk of bias; $\mathrm{B}=$ unclear risk of bias; $\mathrm{C}=$ high risk of bias. Subset "l" suggests that a description was provided, while subset "Il" suggests that no description was provided.

Abbreviation: RCT, randomized controlled trial.

renal outcomes resulting from the weight loss achieved using the VLCDs were variable, but generally, there was either no change or an improvement in hepatic and renal health. This may be due to the fact that these studies measuring kidney and liver outcomes only included adults with normal kidney and liver function, with the exception of NAFLD.

The outcomes in terms of hepatic function were improved in some studies, remained the same in others, and initially increased during the VLCD phase but normalized thereafter in one study. The inconsistencies between these studies are likely to be due to a combination of things, including the different lengths of treatment, different sampling times, as well as different weight maintenance approaches. However, these studies certainly did not demonstrate any negative outcomes for hepatic health in response to a VLCD and subsequent follow up. On the contrary, when looking at the outcomes for NAFLD, the effect of the weight loss achieved by the VLCD resulted in important improvements in NAFLD, most likely due to the associated decrease in visceral adiposity. ${ }^{22}$
These results are supported by our earlier findings ${ }^{12}$ and suggestion that changes in liver enzymes may indicate an improvement in hepatic steatosis. Several other studies have also suggested beneficial effects of weight loss on liver size and adiposity. Colles et $\mathrm{al}^{23}$ observed that during a 12 -week VLCD, most of the reduction in liver size occurred in the first 2 weeks of weight loss, likely due to the depletion of liver glycogen and bound water (caused by the low carbohydrate content of the diet). ${ }^{24}$ Favorable changes were also observed in a range of biochemical and clinical tests (significant decreases in ALKP, bilirubin, ALT, and GGT). Andersen et $\mathrm{al}^{25}$ investigated the effects of weight loss induced by a VLCD on liver morphology and function in morbidly obese but otherwise healthy individuals. They observed a marked improvement in hepatic health, which correlated with the reduction of weight. However, they also observed that $24 \%$ of the patients developed a slight portal inflammation as well as, in $12 \%$ of patients, a slight portal fibrosis. They did not find predictors (morphological or biochemical) for

Table 3 Summary of liver results

\begin{tabular}{|c|c|c|c|c|c|c|c|c|c|c|}
\hline \multirow[t]{2}{*}{ Author } & \multirow[t]{2}{*}{ Patient groups } & \multicolumn{3}{|c|}{ AST (IU/L) } & \multicolumn{3}{|l|}{ ALT (IU/L) } & \multicolumn{3}{|c|}{ ALKP (IU/L) } \\
\hline & & Pre & $\begin{array}{l}\text { Post- } \\
\text { VLCD }\end{array}$ & $\begin{array}{l}\text { Study } \\
\text { end }\end{array}$ & Pre & $\begin{array}{l}\text { Post- } \\
\text { VLCD }\end{array}$ & $\begin{array}{l}\text { Study } \\
\text { end }\end{array}$ & Pre & $\begin{array}{l}\text { Post- } \\
\text { VLCD }\end{array}$ & Study end \\
\hline Arai & SLCD & $26.3(24.5)$ & $16.0(6.4)$ & - & $35.2(39.5)$ & I3.0(8.3) & - & - & - & - \\
\hline et $\mathrm{al}^{16}$ & VLCD & $22.9(18.3)$ & $12.6(4.7)^{c}$ & & $27.6(20.7)$ & $14.1(9.8)^{c}$ & & & & \\
\hline Melin & Group I: intensive & $29.4(5.9)$ & - & No $\Delta$ & $29.4(11.8)$ & - & No $\Delta$ & - & - & - \\
\hline et $\mathrm{al}^{\prime \prime}$ & $\begin{array}{l}\text { Group 2: less } \\
\text { intensive }\end{array}$ & $29.4(5.9)$ & & & $29.4(11.8)$ & & & & & \\
\hline Rolland & VLCD & - & - & - & $30.0(17.8)$ & - & $23.2(8.9)^{\mathrm{a}, \mathrm{b}}$ & $81.6(19.6)$ & - & $77.3(23.0)^{\mathrm{a}}$ \\
\hline et $\mathrm{al}^{12}$ & LCHP & - & - & - & $35.4(23.0)$ & - & $34.5(27.7)$ & $89.1(32.9)$ & - & $84.6(26.7)$ \\
\hline
\end{tabular}


these changes and hypothesized that a fast mobilization of intracellular triacylglycerols and subsequent secretion of fatty acids had induced a portal inflammation, which in turn, led to the fibrosis. They proposed that a rapid mobilization of intra- and extrahepatic fat stores may present a hepatotoxic factor common to all weight loss treatments that induce rapid weight loss. Based on their observations, they postulated that to avoid the development of portal fibrosis during treatment with VLCD, a weight loss slower than $1.6 \mathrm{~kg} /$ week should be recommended.

The issue of the development of fibrosis in the study by Andersen et $\mathrm{al}^{25}$ should not be confused with the development of fibrosis observed in individuals following bariatric surgery, another approach that induces rapid weight loss. Several studies have reported improvements in liver biochemical and histological outcomes following bariatric surgery, ${ }^{26-28}$ but some authors have expressed concern that rapid weight loss may be a causative factor in the occurrence of fibrosis that was observed. ${ }^{27-29}$ However, as Kral et $\mathrm{al}^{28}$ suggest, this may be due to a decreased serum albumin and poorly managed diarrhea, which are two known potential side effects of certain types of bariatric surgery. The problems with hepatic fibrosis are well known ${ }^{30}$ and are probably not related to the rate of weight loss but rather, to surgically induced short bowel syndrome. Certainly, the issue of fibrosis did not figure in the clinical trials highlighted in this systematic review, and such situations are not generally associated with the use of low-calorie diet or VLCD interventions.

Limited information was available regarding the response of renal function to the weight loss induced by VLCD. Nevertheless, the current data suggest either an improvement or no change in response to weight loss induced by a VLCD followed by a weight maintenance period.
Previously, we suggested that improvements in renal function during a VLCD are possible, due to the associated increase in fluid intake and/or reduction in creatine intake. ${ }^{12}$

Obesity-related glomerular disease was first identified by Weisinger et $\mathrm{al}^{31}$ in the 1970 s, and the prevalence of obesityrelated glomerulopathy has been increasing as a consequence of the obesity epidemic. ${ }^{32}$ It has been suggested that reducing the glomerular hyperfiltration observed in the obese may provide a way to prevent or delay the development of renal disease in these individuals. ${ }^{33}$ Indeed, Chagnac et a ${ }^{33}$ demonstrated improvements in GFR following weight loss induced by a gastroplasty. This finding is supported by the review by Navaneethan et al, ${ }^{34}$ in which the researchers reported that in patients with chronic kidney disease, bariatric surgery was associated with a decrease in BMI, with resultant normalization of glomerular hyperfiltration; however, they also stated that it remains to be clarified whether this normalization can result in long-term renal benefits. Previously, we reported an improvement in eGFR following the VLCD. ${ }^{12}$ The use of eGFR, however, is a poor indicator of improved renal function in this case - as a direct result of the use of VLCDs, the intake of creatine drops dramatically, and hence, the serum creatinine also drops, and this may give a false impression of improved renal function. Also, the use of eGFR significantly underestimates measured kidney function with obesity, and measuring changes in eGFR when body surface area is also changing is problematic. ${ }^{35}$

In addition, the use of eGFR has not been validated in patients with normal kidney function.

\section{Strengths and limitations}

The main limitation of this review is the small number of studies included as well as the lack of data presented in many

\begin{tabular}{|c|c|c|c|c|c|c|c|c|}
\hline \multicolumn{3}{|c|}{ GGT (IU/L) } & \multicolumn{3}{|c|}{ Total bilirubin (mol/L) } & \multicolumn{3}{|c|}{ Albumin (g/L) } \\
\hline Pre & Post-VLCD & Study end & Pre & Post-VLCD & Study end & Pre & Post-VLCD & Study end \\
\hline- & - & - & & & & & & \\
\hline $30.0(24.0)$ & - & No $\Delta$ & & & & & & \\
\hline \multicolumn{9}{|l|}{$24.0(12.0)$} \\
\hline $33.8(33.7)$ & - & $24 . I(17.7)^{a, b}$ & $9.1(5.8)$ & - & $9.8(7.3)$ & $43.0(2.5)$ & - & $42.8(2.2)^{\mathrm{a}}$ \\
\hline $48.2(77.4)$ & - & $39.6(51.2)$ & $10.0(3.6)$ & - & $9.4(5.1)^{\mathrm{a}}$ & $45.0(2.4)$ & - & $45.6(5.8)$ \\
\hline
\end{tabular}


of the studies. In addition, the heterogeneity of the studies in terms of study quality, treatment duration, outcomes measured, and time points rendered it impossible to carry out a meta-analysis. It is also important to highlight that only one study ${ }^{16}$ reported hepatic outcomes, and none reported renal outcomes immediately post-VLCD (or during active VLCD) compared with follow up (long after the VLCD was completed).

Finally, in assessing kidney function outcomes, it would have been beneficial to have information about renal blood flow, arterial pressure, and albuminuria.

\section{Conclusion}

There are currently no effective treatments for NAFLD other than weight reduction and lifestyle modification. ${ }^{36,37}$ The effect of VLCDs on hepatic and renal outcomes remains unclear at this stage. There have been a number of improvements observed in terms of hepatic and renal outcomes; however, there may be some concern about the onset of fibrosis in some individuals, although no evidence for this was observed in the current systematic review. Renal outcomes seem little affected by VLCDs; however, the studies measuring kidney function included only adults with normal kidney function, and the results cannot be extrapolated to those with any degree of kidney dysfunction. At this stage, further standardized research is required to fully assess the impact of VLCDs on hepatic and renal health and to better advise clinical practice.

\section{Acknowledgments}

This research was funded by LighterLife Ltd, UK.

\section{Disclosure}

$\mathrm{CR}$ has received lecture honoraria and has attended national/international meetings as a guest of LighterLife Ltd, UK. CR and JB have been involved with other companies with an interest in obesity. JB and KLJ are employed by LighterLife Ltd, UK. The authors report no other conflicts of interest.

\section{References}

1. Wang YC, McPherson K, Marsh T, Gortmaker SL, Brown M. Health and economic burden of the projected obesity trends in the USA and the UK. Lancet. 2011;378(9793):815-825.

2. Mulholland Y, Nicokavoura E, Broom J, Rolland C. Very-low-energy diets and morbidity: a systematic review of longer-term evidence. $\mathrm{Br} \mathrm{J}$ Nutr. 2012;108(5):832-851.

3. van Itallie TB. Liquid protein mayhem. JAMA. 1978;240(2):144.

4. Centers For Disease Control. Liquid Protein Diets. Public Health Service Report. Atlanta, GA: Centers For Disease Control; 1979. 
5. European Food Safety Authority. Scientific opinion on the substantiation of health claims related to very low calorie diets (VLCDs) and reduction in body weight (ID 1410), reduction in the sense of hunger (ID 1411), reduction in body fat mass while maintaining lean body mass (ID 1412), reduction of post-prandial glycaemic responses (ID 1414), and maintenance of normal blood lipid profile (1421) pursuant to Article 13(1) of Regulation (EC) No 1924/2006. EFSA Journal. 2011;9(6):2271-2293.

6. Atkinson RL, Dietz WH, Foreyt JP, et al; National Task Force on the Prevention and Treatment of Obesity, National Institutes of Health. Very low-calorie diets. JAMA. 1993;270(8):967-974.

7. Capstick F, Brooks BA, Burns CM, Zilkens RR, Steinbeck KS, Yue DK Very low calorie diet (VLCD): a useful alternative in the treatment of the obese NIDDM patient. Diabetes Res Clin Pract. 1997;36(2):105-111.

8. Williams KV, Mullen ML, Kelley DE, Wing RR. The effect of short periods of caloric restriction on weight loss and glycemic control in type 2 diabetes. Diabetes Care. 1998;21(1):2-8.

9. Dhindsa P, Scott AR, Donnelly R. Metabolic and cardiovascular effects of very-low-calorie diet therapy in obese patients with Type 2 diabetes in secondary failure: outcomes after 1 year. Diabet Med. 2003;20(4): 319-324.

10. Jazet IM, de Craen AJ, van Schie EM, Meinders AE. Sustained beneficial metabolic effects 18 months after a 30-day very low calorie diet in severely obese, insulin-treated patients with type 2 diabetes. Diabetes Res Clin Pract. 2007;77(1):70-76.

11. Melin I, Karlström B, Lappalainen R, Berglund L, Mohsen R, Vessby B. A programme of behaviour modification and nutrition counselling in the treatment of obesity: a randomised 2-y clinical trial. Int J Obes Relat Metab Disord. 2003;27(9):1127-1135.

12. Rolland C, Hession M, Murray S, Wise A, Broom I. Randomized clinical trial of standard dietary treatment versus a low-carbohydrate/ high-protein diet or the LighterLife Programme in the management of obesity*. J Diabetes. 2009;1(3):207-217.

13. Lim EL, Hollingsworth KG, Aribisala BS, Chen MJ, Mathers JC, Taylor R. Reversal of type 2 diabetes: normalisation of beta cell function in association with decreased pancreas and liver triacylglycerol. Diabetologia. 2011;54(10):2506-2514.

14. Clarke M, Oxman AD, editors. Cochrane Reviewer's Handbook 4.15. In The Cochrane Library. Oxford: Update Software; 2002.

15. Avenell A, Broom J, Brown TJ, et al. Systematic review of the longterm effects and economic consequences of treatments for obesity and implications for health improvement. Health Technol Assess. 2004;8(21):iii-iv, 1.

16. Arai K, Miura J, Ohno M, Yokoyama J, Ikeda Y. Comparison of clinical usefulness of very-low-calorie diet and supplemental low-calorie diet Am J Clin Nutr. 1992;56(Suppl 1):S275-S276.

17. Doherty JU, Wadden TA, Zuk L, Letizia KA, Foster GD, Day SC. Long-term evaluation of cardiac function in obese patients treated with a very-low-calorie diet: a controlled clinical study of patients without underlying cardiac disease. Am J Clin Nutr. 1991;53(4):854-858.

18. Olsson J, Sundberg B, Viberg A, Haenni A. Effect of a vegetable-oil emulsion on body composition; a 12-week study in overweight women on a meal replacement therapy after an initial weight loss: a randomized controlled trial. Eur J Nutr. 2011;50(4):235-242.

19. Ryttig KR, Rössner S. Weight maintenance after a very low calorie diet (VLCD) weight reduction period and the effects of VLCD supplementation. A prospective, randomized, comparative, controlled long-term trial. J Intern Med. 1995;238(4):299-306.
20. Hauner H, Petzinna D, Sommerauer B, Toplak H. Effect of acarbose on weight maintenance after dietary weight loss in obese subjects. Diabetes Obes Metab. 2001;3(6):423-427.

21. Lin WY, Wu CH, Chu NF, Chang CJ. Efficacy and safety of very-lowcalorie diet in Taiwanese: a multicenter randomized, controlled trial. Nutrition. 2009;25(11-12):1129-1136.

22. Vilar L, Oliveira CP, Faintuch J, et al. High-fat diet: a trigger of non-alcoholic steatohepatitis? Preliminary findings in obese subjects. Nutrition. 2008;24(11-12):1097-1102.

23. Colles SL, Dixon JB, Marks P, Strauss BJ, O’Brien PE. Preoperative weight loss with a very-low-energy diet: quantitation of changes in liver and abdominal fat by serial imaging. Am J Clin Nutr. 2006;84(2): 304-311.

24. Olsson KE, Saltin B. Variation in total body water with muscle glycogen changes in man. Acta Physiol Scand. 1970;80(1):11-18.

25. Andersen T, Gluud C, Franzmann MB, Christoffersen P. Hepatic effects of dietary weight loss in morbidly obese subjects. J Hepatol. $1991 ; 12(2): 224-229$.

26. Bhathal PS, Dixon JB, Hughes NR, O'Brien PE. Nonalcoholic fatty liver disease: improvement in liver histological analysis with weight loss. Hepatology. 2004;39(6):1647-1654.

27. Mattar SG, Velcu LM, Rabinovitz M, et al. Surgically-induced weight loss significantly improves nonalcoholic fatty liver disease and the metabolic syndrome. Ann Surg. 2005;242(4):610-620.

28. Kral JG, Thung SW, Biron S, et al. Effects of surgical treatment of the metabolic syndrome on liver fibrosis and cirrhosis. Surgery. 2004; 135(1):48-58.

29. Luyckx FH, Desaive C, Thiry A, et al. Liver abnormalities in severely obese subjects: effect of drastic weight loss after gastroplasty. Int $J$ Obes Relat Metab Disord. 1998;22(3):222-226.

30. Friedman SL. The cellular basis of hepatic fibrosis. Mechanisms and treatment strategies. N Engl J Med. 1993;328(25):1828-1835.

31. Weisinger JR, Kempson RL, Eldridge FL, Swenson RS. The nephrotic syndrome: a complication of massive obesity. Ann Intern Med. 1974;81(4):440-447.

32. Mokdad AH, Serdula MK, Dietz WH, Bowman BA, Marks JS, Koplan JP. The spread of the obesity epidemic in the United States, 1991-1998. JAMA. 1999;282(16):1519-1522.

33. Chagnac A, Weinstein T, Herman M, Hirsh J, Gafter U, Ori Y. The effects of weight loss on renal function in patients with severe obesity. J Am Soc Nephrol. 2003;14(6):1480-1486.

34. Navaneethan SD, Yehnert H, Moustarah F, Schreiber MJ, Schauer PR, Beddhu S. Weight loss interventions in chronic kidney disease: a systematic review and meta-analysis. Clin J Am Soc Nephrol. 2009;4(10) $1565-1574$

35. Delanaye P, Radermecker RP, Rorive M, Depas G, Krzesinski JM. Indexing glomerular filtration rate for body surface area in obese patients is misleading: concept and example. Nephrol Dial Transplant. 2005; 20(10):2024-2028.

36. Suzuki A, Lindor K, St Saver J, et al. Effect of changes on body weight and lifestyle in nonalcoholic fatty liver disease. J Hepatol. 2005;43(6) 1060-1066.

37. Clark JM. Weight loss as a treatment for nonalcoholic fatty liver disease. J Clin Gastroenterol. 2006;40(Suppl 1):S39-S43.

Diabetes, Metabolic Syndrome and Obesity: Targets and Therapy

\section{Publish your work in this journal}

Diabetes, Metabolic Syndrome and Obesity: Targets and Therapy is an international, peer-reviewed open-access journal committed to the rapid publication of the latest laboratory and clinical findings in the fields of diabetes, metabolic syndrome and obesity research. Original research, review, case reports, hypothesis formation, expert opinion and commentaries are all considered for publication. The manuscript management system is completely online and includes a very quick and fair peer-review system, which is all easy to use. Visit http://www.dovepress.com/testimonials.php to read real quotes from published authors. 